\title{
Entrepreneurial Inclination of Students at a Private University in Malaysia
}

\author{
Manjit Singh Sandhu
}

Kamal Kishore Jain

Mohar Yusof

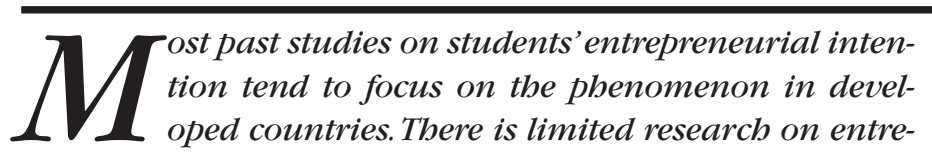
preneurial intention of university students from developing nations. This article intends to close this gap by providing some insights into students' entrepreneurial inclination in a developing country, Malaysia. A total of 234 students from three faculties at both graduate and undergraduate levels were surveyed to examine their entrepreneurial inclination and also to examine the relationship between their demographic and social characteristics with entrepreneurial inclination. The study found strong entrepreneurial inclination among the students. Significant difference was found between students studying part time and full time and their entrepreneurial inclination. Significant difference was also found between the type of program enrolled in and students' entrepreneurial inclination. Further analysis and other findings were reported and recommendation for future research are been put forth in this article.

Keywords: entrepreneurship, entrepreneurial inclination, entrepreneurship education

Research on entrepreneurship has been growing over the past few decades (Alstete 2002; Klapper 2004; Frank et al. 2005; Gurol and Atsan 2006). This has been mainly due to the importance of entrepreneurship in driving economic development and employment (Gorman, Hanlan, and King 1997; Brockhaus 1991). The Global Entrepreneurship Monitor (GEM) report 2007 indicated strong variations across developed and developing countries in terms of participation in entrepreneurial activities (Bosma et al. 2007). Most developed countries such as Italy, Greece, and Spain showed higher entrepreneurial participation rates. Developing countries, however, were still behind with the exception of countries such as China, Romania, and Thailand, where participation rates had picked up (Bosma et al. 2007). Malaysia did not participate in the GEM study.This research gap makes this study relevant and timely.

In Malaysia, the development of entrepreneurship became a national agenda and priority with the establishment in 1995 of a separate ministry known as Ministry of Entrepreneur Development. The creation of this ministry was timely with graduate unemployment rising to 60,000 in 2005. That data also implied that economic growth had created fewer jobs than it used to and thus made it more difficult for people to obtain jobs (Ngui 2005). The issue of graduate unemployment and attitude of current graduates who were seen to be too pampered and dependent on the government and private organizations for employment were therefore considered a major concern.

Entrepreneurship needs to be encouraged and promoted among Malaysian university students so that they have more options upon graduation. In this context, it is appropriate to determine if our existing university students are inclined toward entrepreneurship. This will help in developing a clear-cut policy to promote entrepreneurship at the national level so that future generations of graduates can be encouraged and motivated to become entrepreneurs. Since entrepreneurship has been accepted as a potential catalyst and incubator for technological progress, product, and market innovation (Mueller and Thomas 2000; Jack and Anderson 1999), we believe these benefits will help augment Malaysian economy as well.

There is limited research on entrepreneurial intention of university students from developing nations. A brief review of the literature shows that most past studies on students' entrepreneurial intention tend to focus on developed countries (Krueger, Reilly, and Carsrud 2000; Guerrero, Rialp, and Urbano 2008; Koh 1995; Audet 2002; Tkachev and Kolvereid 1999; Gnoth 2006). This research intends to close this gap by providing some insights into students' entrepreneurial intention in the developing country of Malaysia.

The purpose of this research is to examine the degree to which the younger generation is inclined toward entrepreneurship. Specifically, this research aims

1. to examine the relationship between students' demographic characteristics and their entrepreneurial inclination,

2. to identify if any significant difference in the entrepreneurial inclination between full-time and part-time students,

3. to identify if any significant difference in the entrepreneurial inclination between undergraduate and postgraduate students; and 
4. to identify if any significant difference between type of program enrolled in and students' entrepreneurial inclination.

\section{About UNITAR and Malaysia}

University Tun Abdul Razak (UNITAR) is Malaysia's first elearning, MSC-status and ISO 9001:2000-certified private university in Malaysia. UNITAR offers the best combination in its teaching and e-learning methods by combining face-to-face classes with the effective use of web-based courseware and online tutorials. UNITAR currently offers 28 academic programs, 11 of which are accredited by the National Accreditation Council. All UNITAR programs are approved by the Private Education Department. Its programs range from foundation and diploma up to doctorate degrees in fields such as information technology, business administration, humanities and social sciences, and hospitality and tourism management (http://www.unitar.edu.my).

Malaysia, a multicultural society whose population in 2008 was 27.73 million, consists of various multiethnic groups such as Malays and other indigenous people (65\%), Chinese (26\%), and Indians (8\%) (Department of Statistics 2008). The national language is Malay but English is widely spoken and is the main business language in the private sector. Islam is the main religion practiced followed by other religions such as Buddhism, Christianity, and Hinduism. Historically, the Chinese, and to an extent the Indian-Muslim community, have had a long tradition of entrepreneurship. In contrast, the "Bumiputera" (sons of the soil) community has not inherited the tradition of entrepreneurship. Rather, they have been used to being either employed in the government service or self-employed in agriculture as tillers or smallholders (Ariff and Syarisa Yanti 2002).

\section{Literature Review}

\section{Definition of Entrepreneurship}

An entrepreneur can be defined as a person who creates a new business in the face of risk and uncertainty for the purpose of achieving profit and growth by identifying opportunities and assembling the necessary resources to capitalize on them (Zimmerer and Scarborough 2002). Whereas, entrepreneurship is the process of creating something new with value by devoting necessary time and effort, assuming the accompanying financial, psychic, and social risks, and receiving the resulting rewards of monetary and personal satisfaction and independence (Hisrich and Peters 2002).

It is a multifaceted activity that has been defined by Timmons (1989: 1) as "the ability to create something from practically nothing." According to Cromie (2000), "Entrepreneurship is initiating ... and building an enterprise rather than ... watching one. It is the knack of sensing opportunities where others see chaos, contradiction, and confu- sion. It is the ability to build a 'founding team' to complement your own skills and talents. It is the knowledge to find, marshal, and control resources. . . Finally it is a willingness to take risks.”

Although it is possible that some will argue otherwise, it seems evident that much of what we consider "entrepreneurial" activity is intentionally planned behavior (Krueger, Reilly and Carsrud 2000). We best predict, rather than explain, any planned behavior by observing intentions toward that behavior-not by attitudes, beliefs, personality, or mere demographics. Intentions are the single best predictor of planned behavior (Bagozzi, Baumgartner, and Yi 1989). Understanding intentions thus proves particularly valuable where the focal phenomenon is rare, obscure, or involves unpredictable time lags-a focal phenomenon such as entrepreneurship (MacMillan and Katz 1992).

\section{Theories on Entrepreneurship}

A survey of the literature reveals numerous theories on entrepreneurship. However, each theory tends to focus on different attributes and areas. For example, there is the psychological school of thought that relates entrepreneurship with personality traits such as need for achievement, locus for control, risk taking behavior (McClelland 1987; Dyer 1994). Institutional economic theory, on the other hand, explains entrepreneurship motives by relating it to informal institutional factors such as attitudes and norms of behavior (Krueger and Brazeal 1994) and formal institutional factors such as policies, laws, regulations, government assistance, and culture (North 1990). This research examines the entrepreneurial intention or inclination of students and therefore, both these theories are not relevant.

A review of entrepreneurship intentional models reveals two important theories: Theory of Planned Behavior (TPB) and Shapero's Entrepreneur Event Model (1982).TPB focuses on how people's intention may influence entrepreneurial behavior (Ajzen 1987; 1991). Shapero's Entrepreneur Event Model (1982) is another intentional model but based on perception toward desirability and feasibility to act upon opportunities. Previous empirical research conducted found that both these models are useful to predict entrepreneurial intention (Krueger, Reilly, and Carsrud 2000). Intention is in fact found to be the best predictor of planned behavior since behavior itself is difficult to observe and predict (Bagozzi, Baumgartner, and Yi 1989). This clearly shows that research on entrepreneurial intention or inclination is very vital and should be conducted regularly to predict the planned behavior of people venturing into entrepreneurship. In the case of university students, these are future potential entrepreneurs who can be nurtured to become successful entrepreneurs and lead the way forward. 


\section{Empirical Perspectives on Entrepreneurial Intention}

A review of the literature reveals quite a number of empirical studies in the last few years that focused on entrepreneurial intention. However, many of these studies were conducted in developed countries (Veciana, Aponte, and Urbano 2005; Lee et al. 2006; Kolvereid 1996; Koh 1995; Tkachev and Kolvereid 1999; Peterman and Kennedy 2003; Guerrero, Rialp and Urbano 2008; Wang and Wong 2004; Li 2007).

Veciana, Aponte, and Urbano (2005) conducted an extensive study of entrepreneurial perception of university students in Puerto Rico (435 students) and Catalan (837). Their study examined new venture desirability, feasibility, and serious intention of setting up new ventures. For the Puerto Rico sample, 90 percent of the students showed high desirability, 53 percent showed high feasibility, and only 29 percent showed serious intention to set up a new venture. For the Catalan sample, 74 percent showed high desirability, 66.1 percent showed high feasibility, and only 12 percent showed serious intention to set up a firm. This result corroborated the findings from other studies in Catalan where more than 70 percent of the students showed high entrepreneurial intention (Guerrero, Rialp, and Urbano 2008). In addition, the entrepreneurial intention was higher than similar studies conducted in Spain in the mid-80s (Genesc'a and Veciana 1984).

Another extensive study covering students from the United States, Korea, Fiji, and China was conducted by Lee et al. (2006). American and Chinese students showed weak intention for venture creation with mean values less than 3.0 on a five-point Likert scale. Lee et al. (2006) argued that low intention among American students was due to the prosperous American economy that was able to provide more job opportunities. Lee et al. (2006) further argued that the low intention among Chinese students was due to China's challenging legal environment for new venture creation and the lack of financial support from the state. However, students from Korea and Fiji showed high intention for venture creation (mean values of 3.34 and 3.12 respectively). Lee et al. (2006) argued that high intention among Korean students was due to the challenging environment in Korea after the financial crisis and in the case of Fiji, the lack of economic opportunities faced by people in that country. Lee et al. (2006) further recommended a customized approach for entrepreneurship education to be more effective.

With regard to the relationship between demographic factors and entrepreneurial intention, results had been mixed and inconclusive. Gender was found to influence entrepreneurial intention in some studies and male students tended to show higher intention levels than female (Kolvereid 1996; Wang and Wong 2004; Veciana, Aponte, and Urbano 2006). However, a study of 512 medical and technical students in
Russia did not support this finding. Gender was found not to be correlated with entrepreneurial intention (Tkachev and Kolvereid 1999). Female students' entrepreneurial intention was higher in another study conducted in Spain (Guerrero, Rialp, and Urbano 2008).

Family involvement in business was also found to influence entrepreneurial inclination of students in a number of countries such as in Hong Kong (Koh 2005), Norway (Kolvereid 1996), Catalan (Veciana, Aponte, and Urbano 2006) and Singapore (Wang and Wong 2004). However, Tkachev and Kolvereid (1999), in their study in Russia, found no significant correlation between family involvement and entrepreneurial intention.

Past research had also shown that students taking entrepreneurship-related courses were more inclined toward becoming entrepreneurs. For example, Peterman and Kennedy (2003) in a study on students' entrepreneurial inclination in Queensland, Australia, found that entrepreneurship education had positive effect on entrepreneurship desirability. This was corroborated by another research in Catalan (Guerrero, Rialp, and Urbano 2008).

Age and work experience were also found to influence entrepreneurial intention. Work experience was found to have a positive effect on self-employment (Bates 1990; Schiller and Crewson 1997). However, the respondents in these studies were not students. Another study by Evans and Leighton (1989) found that for the first 20 years, experience did not influence people to become entrepreneurs and age was therefore, not a factor in influencing entrepreneurial intention. Miller (1984), on the other hand, found that young people tended to take more risk.

\section{Malaysian Perspective}

In Malaysia, research on entrepreneurship is still very limited. This may be due to the fact that this field has only begun to be emphasized by the government in the mid-90s when the Ministry of Entrepreneur Development was created in 1995. Most of the existing research on entrepreneurship in Malaysia tend to focus, generally, on the broad area of small and medium enterprises (SMEs), the success factors of actual entrepreneurs, and to a certain extent characteristics of entrepreneurs (Nor, Ezlika, and Ong 2000; Nor Aishah and Yufiza 2004; Ariff and Syarisa Yanti 2002; Noor and Ali 2004).

Only two empirical research studies conducted by Kamariah,Yaacob, and Wan Jamaliah (2004) and Ramayah and Harun (2005) were found to examine university students' entrepreneurial intention. The former covered a private university and found that there was high degree (86\% of 279 respondents) of entrepreneurial intention among the students. High degree of entrepreneurial intention was also found among students across programs and not confined to business students only. Students' exposure to entrepreneurial 
courses was also found to have significant relationship with entrepreneurial intention (Kamariah, Yaacob, and Wan Jamaliah 2004). The latter research was conducted covering 1,281 students in Science University of Malaysia, one of the largest research universities in the country. The findings from this research were as follows: (1) male students had higher entrepreneurial intention than female students; (2) science students tended to show more entrepreneurial intention as compared to arts students; (3) those who had exposure to entrepreneurship courses had higher entrepreneurial intention; and, (4) no significant difference was found among various ethnic groups and their entrepreneurial intention which indicated that ethnicity did not influence entrepreneurial inclination (Ramayah and Harun 2005).

Other studies in Malaysia covering local business contractors and local youths also found strong relationship between exposure to entrepreneurship education and entrepreneurial intention (Nor Aishah and Yufiza 2004; Jumaat, Ishak, and Salehuddin 2001). Yusop (2002) found positive influence of family involvement in business on entrepreneurial inclination. However, in a study of contractors, Nor Aishah and Yufiza (2004) found that majority (73\%) who became entrepreneurs were motivated by their own interest and 66 percent were not from families with a business background. In a study of urban entrepreneurs, Nor, Ezlika, and Ong (2004) found that majority of them were male and without tertiary education. However, this finding tended to cover sectors dominated by male and as such would not be representative of other groups.

\section{Methodology \\ Data Collection}

Survey-based methodology was used in this research to obtain data from the respondents, namely undergraduate and postgraduate students from UNITAR. Data collection for this study began in March 2006 and ended in early June 2006. The data was collected through a self-administered questionnaire. The questionnaire was divided into two sections: Section A comprised questions eliciting demographic and other personal characteristics; Section B comprised of 12 questions designed to gather information from respondents regarding their perception and inclination toward entrepreneurship. These items were adopted based on the extensive literature review. A five-point Likert scale was used in this section and the respondents were required to state the extent to which they agreed or disagreed with the statements in the questionnaire. Due to time limitations, the sampling was based on convenience and from the 550 questionnaires distributed, 234 questionnaires were successfully collected (42\% response rate) and were found to be complete and usable for data analysis. Total student population at the main campus of the university during the time of research was around 3,000 students. Classrooms where teaching was going on were randomly chosen and the completed questionnaires were collected then and there.

\section{Reliability Analysis}

A Cronbach coefficient alpha test was conducted on the 12 items in Section B to determine internal consistency of the scale used.According to Sekaran (2000), Cronbach alpha is a reliability coefficient that indicates how well the items are positively correlated to one another. The closer the Cronbach alpha is to 1 , the higher the internal consistency. Items 9, 10 and 11 in the questionnaire were negatively worded and were recoded prior to the analysis. Based on the guidelines by Sekaran (2000), a scale of 0.6 is considered to be poor, 0.7 is acceptable, and those over 0.8 are good. The values of Cronbach alpha coefficient are depicted in Table 1. Itemwise, alpha was also calculated and it was discovered that if item 6 from Section $B$ was deleted, then the value of the alpha increased slightly. Since there was only marginal change in the value of Alpha if item 6 was deleted, the authors decided to retain this item.

\begin{tabular}{|l|l|l|}
\hline \multicolumn{2}{|c|}{ Table 1. Reliability Statistics } \\
\hline Cronbach's Alpha & $\begin{array}{l}\text { Cronbach Alpha } \\
\text { Based on } \\
\text { Standardized Items }\end{array}$ & N Items \\
\hline .724 & .737 & 12 \\
\hline
\end{tabular}

\section{Data Analysis \\ Demographic and Personal Characteristics of the Sample}

Based on the demographic characteristics provided in Table 2 , one can observe that the majority of the respondents were female (67.5\%) and were between 21-25 years of age (71.4\%). In terms of race, the majority were Malay (51.3\%), followed by Indians (25.2), Chinese (15\%), and others (8.5\%). Of the total respondents, 86.3 percent were undergraduates, with the remaining 13.7 percent being postgraduate students. In addition, 67.5 percent of the respondents were fulltime students, compared to 32.5 percent who were studying on a part-time basis. This was not surprising since the university attracted a large number of part-timers due to its flexible teaching mode.

\section{Means and Frequency Distribution of Responses to the Construct on Entrepreneurial Inclination}

Table 3 depicts a tabulation of the means and frequency distribution of responses to the 12 items in Section $B$ of the questionnaire. It can be seen from this table that the mean score (except for two items) is more than 3, which shows 
Table 2. Frequency Distributions of Sample $(n=234)$

\begin{tabular}{|c|c|c|}
\hline Demographic & Frequency & Percentage \\
\hline $\begin{array}{l}\text { Gender } \\
\text { Male } \\
\text { Female }\end{array}$ & $\begin{array}{r}76 \\
158\end{array}$ & $\begin{array}{l}32.5 \\
67.5\end{array}$ \\
\hline $\begin{array}{l}\text { Age } \\
<20 \\
21-25 \\
26-30 \\
>30\end{array}$ & $\begin{array}{r}8 \\
167 \\
32 \\
27\end{array}$ & $\begin{array}{r}3.4 \\
71.4 \\
13.7 \\
11.5\end{array}$ \\
\hline $\begin{array}{l}\text { Race } \\
\text { Malay } \\
\text { Chinese } \\
\text { Indian } \\
\text { Others }\end{array}$ & $\begin{array}{r}120 \\
35 \\
59 \\
20\end{array}$ & $\begin{array}{r}51.3 \\
15.0 \\
25.2 \\
8.5\end{array}$ \\
\hline $\begin{array}{l}\text { Student status } \\
\text { Full time } \\
\text { Part time }\end{array}$ & $\begin{array}{r}158 \\
76\end{array}$ & $\begin{array}{l}67.5 \\
32.5\end{array}$ \\
\hline $\begin{array}{l}\text { Student education level } \\
\text { Undergraduate } \\
\text { Postgraduate }\end{array}$ & $\begin{array}{r}202 \\
32\end{array}$ & $\begin{array}{l}86.3 \\
13.7\end{array}$ \\
\hline $\begin{array}{l}\text { Work status } \\
\text { Full time } \\
\text { Part time } \\
\text { Not working }\end{array}$ & $\begin{array}{r}87 \\
44 \\
103\end{array}$ & $\begin{array}{l}37.2 \\
18.8 \\
44.0\end{array}$ \\
\hline $\begin{array}{l}\text { Program enrolled } \\
\text { Bachelor of IT } \\
\text { Bachelor of }\end{array}$ & 13 & 5.6 \\
\hline $\begin{array}{l}\text { Business Administration } \\
\text { Bachelor of } \\
\text { Information System }\end{array}$ & $\begin{array}{l}94 \\
13\end{array}$ & $\begin{array}{r}40.2 \\
5.6\end{array}$ \\
\hline Bachelor of Management & 30 & 12.8 \\
\hline Bachelor of Education & 30 & 12.8 \\
\hline $\begin{array}{l}\text { Bachelor of English } \\
\text { Bachelor of } \\
\text { Hospital and Tourism }\end{array}$ & $\begin{array}{r}1 \\
21\end{array}$ & $\begin{array}{l}0.4 \\
9\end{array}$ \\
\hline $\begin{array}{l}\text { Master in } \\
\text { Information Technology }\end{array}$ & 2 & 0.8 \\
\hline $\begin{array}{l}\text { Master in } \\
\text { Technology Management } \\
\text { Master in } \\
\text { Business Administration }\end{array}$ & 28 & $\begin{array}{l}0.8 \\
12\end{array}$ \\
\hline
\end{tabular}

high entrepreneurial inclination of students. This method was also used by other researchers (Lee et al. 2006; Ramayah and Harun 2005; Kamariah, Yaacob, and Wan Jamaliah 2004). A low mean score for item 11 ("five to seven years from now I see myself doing a job in some company") actually indicates low preference for choosing a job, which again is an indication of high entrepreneurial inclination (self-employment). For item 6 ("I will not mind dropping out of my studies if some good business opportunity comes my way"), a low score may mean that even though respondents have entrepreneurial inclination, education is still important to them.

The responses in Table 3 have also been categorized into three columns: "strongly disagree and disagree," "neutral," and "strongly agree and agree." The proportion of responses for "strongly agree and agree" to "strongly disagree and disagree" is much higher, indicating a strong entrepreneurial inclination. However, the response rate in the category of "neutral" is also very high, indicating the state of indecisiveness of the respondents.

From the 12 items that are used to examine the perception toward entrepreneurial inclination, four (items 1, 2, 4, and 5) are directly measuring the entrepreneurial intention of the students. High frequency of responses for items 2, 4 and 5 is an indication of strong entrepreneurial inclination among the respondents. Of the respondents, 85 percent agreed that they have a strong desire to be the owner of their own businesses, 71 percent were interested in starting their own businesses, and 65 percent saw themselves becoming some type of entrepreneur one day. However, the inclination to start a business is not immediate. The students seemed to be more inclined to start or own a business later in their lives as shown in the responses for items $1,4,11$, and 12 .

These results are comparable to other studies that also reported high entrepreneurial inclination among students (Lee et al. 2006; Veciana, Aponte, and Urbano 2005; Guerrero, Rialp, and Urbano 2008; Kamariah, Yaacob, and Wan Jamaliah 2004). It is important to highlight further that the mean values for all the 4 items $(1,2,4$, and 5$)$ are above 3.7 , which is much higher than the neutral score. In their study in Malaysia, Ramayah, and Harun (2005) had also found high entrepreneurial inclination but their mean scores were only slightly above the neutral point.

Based on the responses to items 7, 9, and 10, one can observe that not many respondents agree and most respondents were indecisive as to whether the Malaysian social and economic environment was supportive of entrepreneurship, whether the economic conditions were favorable for entrepreneurs, or whether there were many business/entrepreneurial opportunities in the Malaysian society. This could indicate that the students might not be aware of the support system, incentives, and schemes that have been made available by the Malaysian government. In addition, the students might not be able to relate and understand the impact of external environmental factors on entrepreneurship, for example, the impact of graduate unemployment on entrepreneurship. This view may indicate that more should be done 
Table 3. Mean and Frequency Distribution of Responses $(n=234)$

\begin{tabular}{|c|c|c|c|c|}
\hline Items & Mean & $\begin{array}{l}\text { Strongly Disagree } \\
\text { and Disagree (\%) }\end{array}$ & Neutral (\%) & $\begin{array}{l}\text { Strongly Agree } \\
\text { and Agree (\%) }\end{array}$ \\
\hline $\begin{array}{l}\text { 1. I have strong plans to venture into business once I } \\
\text { complete my studies. }\end{array}$ & 3.73 & 8.5 & 31.1 & 57.6 \\
\hline 2. I am interested in starting my own business. & 3.92 & 8.3 & 17.4 & 71.4 \\
\hline 3. I am always inclined toward entrepreneurship. & 3.56 & 7.0 & 41.5 & 48.6 \\
\hline $\begin{array}{l}\text { 4. I see myself becoming some type of } \\
\text { entrepreneur one day. }\end{array}$ & 3.77 & 7.5 & 24.9 & 64.7 \\
\hline 5. I have strong desire to be the owner of my business. & 4.01 & 4.5 & 17.4 & 85.1 \\
\hline $\begin{array}{l}\text { 6. I will not mind dropping out of my studies if some } \\
\text { good business opportunity comes my way. }\end{array}$ & 2.58 & 51.5 & 22.4 & 23.2 \\
\hline $\begin{array}{l}\text { 7. Malaysian social and economic environment is highly } \\
\text { supportive of entrepreneurship. }\end{array}$ & 3.45 & 7.0 & 44.8 & 45.2 \\
\hline 8. Entrepreneurs are highly respected in our society. & 3.69 & 2.5 & 37.3 & 57.3 \\
\hline $\begin{array}{l}\text { 9. Present economic conditions, in the wake of } \\
\text { globalization, are not favorable for entrepreneurs. }\end{array}$ & 3.00 & 26.1 & 45.2 & 25.7 \\
\hline $\begin{array}{l}\text { 10. There are not many business/entrepreneurial } \\
\text { opportunities in Malaysian society. }\end{array}$ & 3.09 & 26.1 & 36.9 & 34.0 \\
\hline $\begin{array}{l}\text { 11. Five to seven years from now I see myself doing a job } \\
\text { in some company. }\end{array}$ & 2.75 & 42.8 & 33.6 & 20.7 \\
\hline $\begin{array}{l}\text { 12. Planning for some kind of business has been, is, or will } \\
\text { be an important part of my college career. }\end{array}$ & 3.66 & 6.8 & 36.3 & 56.8 \\
\hline
\end{tabular}

to motivate, create awareness, and offer support to enhance interest in entrepreneurship.

\section{T-test for Gender, Student Status, Occupation, and Degree}

A T-test was conducted to determine if there existed any significant differences between male and female students with regard to their inclination toward entrepreneurship. Levene's test showed p-value of greater than 0.05 and hence homogeneity of variances existed (one of the assumptions for independent group t-test). The t-value and corresponding $\mathrm{p}$-value were not significant at the 5 percent level of significance. Thus, we conclude that there exist no significant difference between the means of male and female in regard to their inclination toward entrepreneurship. The results are depicted in Table 4. This finding corroborates with other studies that found no relationship between gender and entrepreneurial intention (Tkachev and Kolvereid 1999). However, this finding does not support similar research in Malaysia by Ramayah and Harun (2005) that found males to have higher entrepreneurial intention than female students. A study by Gupta and Turban (2008) found that female students reported greater entrepreneurial intention and men reported lower intention when entrepreneurship was explicitly linked with masculine characteristics compared with when it was implicitly linked with the same characteristics. This aspect may be of interest in future studies conducted in Malaysia.

A T-test was conducted to determine any significant differences existed between students enrolled full time and part time with regard to their inclination toward entrepreneurship. Levene's test showed p-value greater than 0.05 and hence homogeneity of variances existed (one of the assump- 
Table 4. T-test for Gender, Student Status, Occupation, and Degrees

\begin{tabular}{|l|l|l|l|l|l|}
\hline Variable & $\begin{array}{l}\text { Levene's test for } \\
\text { equality of } \\
\text { variance }\end{array}$ & \multicolumn{4}{|l|}{ t-test for equality of means } \\
\hline & $\mathrm{F}$ & Sig. & $\mathrm{t}$ & $\mathrm{df}$ & $\begin{array}{l}\text { Sig. (2 } \\
\text { tail) }\end{array}$ \\
\hline Gender & 3.766 & 0.054 & 0.583 & 232 & 0.560 \\
\hline $\begin{array}{l}\text { Student } \\
\text { status }\end{array}$ & 3.496 & 0.063 & -1.749 & 232 & $0.082^{*}$ \\
\hline $\begin{array}{l}\text { Work } \\
\text { status }\end{array}$ & 8.107 & 0.051 & -0.339 & 129 & 0.735 \\
\hline $\begin{array}{l}\text { Degree } \\
\text { status }\end{array}$ & 6.054 & 0.015 & -0.669 & 36.680 & 0.508 \\
\hline
\end{tabular}

${ }^{*}$ Significant at $10 \% \mathrm{Sig}$. level

tions for independent group t-test). The t-value and corresponding p-value were found to be significant at the 10 percent level of significance. Thus, we conclude that there exists significant difference between students enrolled full time versus part time with regard to their inclination toward entrepreneurship. Mean value of the students enrolled in fulltime courses (3.74) was lower than the mean value of the students enrolled in part-time courses (3.93). The reason for this was that many part-time students were already involved in some entrepreneurial activities. Those who were doing some jobs perhaps enrolled for higher education because of dissatisfaction with their jobs. The results are depicted in Table 4.

A T-test was also conducted to determine if there existed any significant differences between those students working full time and working part time with regard to their inclination toward entrepreneurship. Levene's test showed p-value greater than 0.05 and hence homogeneity of variances existed (one of the assumptions for independent group t-test).The $\mathrm{t}$-value and corresponding $\mathrm{p}$-value were found to be not significant at the 5 percent level. Thus, we conclude that there exists no significant difference between those working part time versus working full time with regard to their inclination toward entrepreneurship. The mean score indicating entrepreneurial inclination for both the groups was found to be very high (around 4). It seems that both groups of respondents, those working full time and those working part time, had pursued higher education because of some kind of dis- satisfaction with their jobs and wanted to become entrepreneurs to overcome their work problems. The results are depicted in Table 4.

A T-test was conducted to determine if there existed any significant differences between undergraduate and postgraduate students with regard to their perception toward entrepreneurship. Levene's test showed p-value of less than 0.05 and hence homogeneity of variances did not exist.The t-value and corresponding $\mathrm{p}$-value were found to be not significant at the $5 \%$ level. Thus, we conclude that there exists no significant difference between undergraduate and postgraduate students with regard to their inclination toward entrepreneurship. The results are depicted in Table 4.

\section{Analysis of Variances (ANOVA)}

In the cases of race and programs enrolled, ANOVA tests were conducted to determine if there existed differences between their means and their inclination toward entrepreneurship. No significant difference was found between the various races and their inclination toward entrepreneurship. This research shows that ethnicity does not have any influence on entrepreneurial intention. The F-value and the corresponding $p$-value were found to be not significant $(p>0.05)$. However, significant difference was found between students from the various programs and their inclination toward entrepreneurship. Further analysis is depicted below. The Fvalue and the corresponding $p$-value were found to be significant $(p>0.05)$. The results are depicted in Table 5.

Due to the small sample size in some programs, it was decided that the programs be regrouped into faculties. This resulted in three faculties: Information Technology (IT), Business (BUS), and Humanities (HUM). ANOVA was again conducted to find out if there were significant differences in the entrepreneurial inclination among various faculties. Significant difference was found between the respondents from IT and Business faculties. Significant difference was also found between the respondents from the Business and Humanities faculties. However, no significant difference was found between the respondents from the IT and Humanities

Table 5. ANOVA for Race and Programs Enrolled

\begin{tabular}{|l|l|l|l|l|l|}
\hline \multicolumn{3}{|l|}{ Variable } & \multicolumn{2}{l|}{ ANOVA for equality of means } \\
\hline & $\begin{array}{l}\text { Sum of } \\
\text { squares }\end{array}$ & df & $\begin{array}{l}\text { Mean } \\
\text { Square }\end{array}$ & F & Sig. (2 tail) \\
\hline Race & 74.848 & 3 & 24.949 & 0.844 & 0.471 \\
\hline $\begin{array}{l}\text { Program } \\
\text { enrolled }\end{array}$ & 586.500 & 9 & 65.167 & 2.322 & $0.016^{*}$ \\
\hline
\end{tabular}

*Significant at $5 \%$ Sig. level 
faculties. This indicates that when Business students are included in the analysis, they tend to influence the level of significance between the means. This result shows that business students tend to have some influence on entrepreneurial intention. Furthermore, it is an interesting finding since other studies by Kamariah, Yaacob, and Wan Jamaliah (2004) found no significant difference among students across programs. Ramayah and Harun (2005) in their study found Science students to be more inclined than Arts students. On the contrary, when science and engineering students in the UK and France were exposed to entrepreneurship programs, their post-program mean values of subjective norm and intention toward self-employment were increased in relation to the pre-program ones (Vangelis, Stefania, and Andreas 2007). Table 6 depicts the ANOVA results conducted between the various faculties.

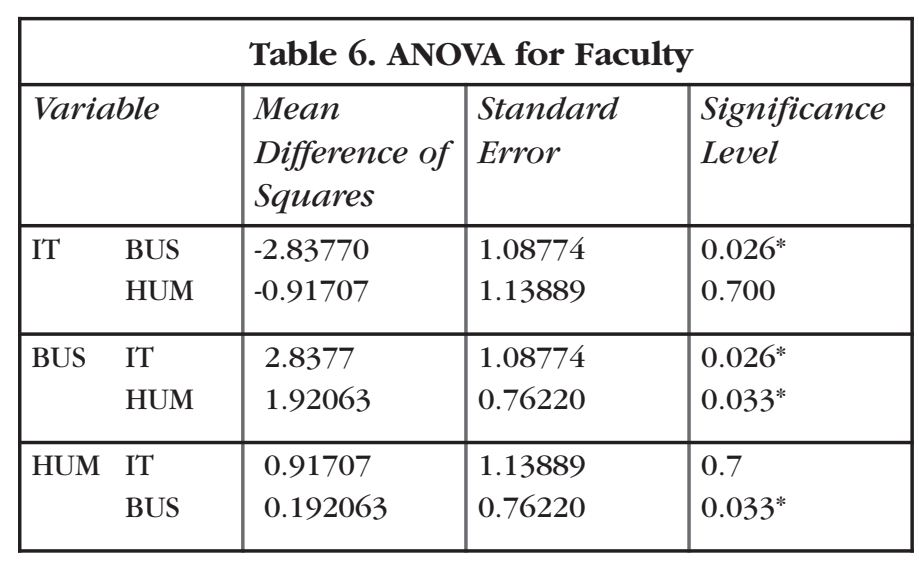

"Significant at $10 \%$ Sig. level

\section{Chi-square Test of Association}

Chi-square test was conducted to examine if there was any association between some of the demographic and personal characteristics with entrepreneurial inclination. No association was found between students' age and entrepreneurial inclination. An examination of the respondent profile reveals that majority are young and less than 30 years old (88\%). Therefore, these young students may not be interested to go into business since they do not have enough experience.This corroborates with a past finding that argued that for the first 20 years, experience may not influence people to become entrepreneurs (Evans and Leighton 1989). However, studies in Western countries found that more young people between the ages of 24-44 tend to venture into business (Reynolds, Hay, and Camp 1999).

In addition, no association was found between students' gender and entrepreneurial inclination. However, significant association was found (10\% significance level) between family involvement in business and entrepreneurial inclination. This supports findings from other developed nations that found family involvement in business to have association with entrepreneurial intention (Koh 2005; Kolvereid 1996;
Veciana, Aponte, and Urbano 2006; Wang and Wong 2004). No association was also found between students who took entrepreneurship courses and entrepreneurial inclination. This result is surprising since it is against the findings of other studies that found positive association between entrepreneurship education and entrepreneurial intention (Peterman and Kennedy 2003; Guerrero, Rialp, and Urbano 2008; Kamariah, Yaacob, and Wan Jamaliah 2004; Ramayah and Harun 2005). The results are depicted in Table 7.

\begin{tabular}{|l|l|l|l|}
\hline \multicolumn{4}{|c|}{$\begin{array}{c}\text { Table 7. Chi-square Test for Age, Gender, Family } \\
\text { Involvement in Business and Involvement in } \\
\text { Entrepreneurship Courses }\end{array}$} \\
\hline Variable & $\begin{array}{l}\text { Pearson } \\
\text { Chi-Sq }\end{array}$ & $d f$ & Sig. Level (2-sided) \\
\hline Age & 67.322 & 78 & 0.8 \\
\hline Gender & 20.232 & 26 & 0.78 \\
\hline $\begin{array}{l}\text { Family involvement } \\
\text { in business }\end{array}$ & 36.427 & 26 & $0.084^{*}$ \\
\hline $\begin{array}{l}\text { Taken entrepre- } \\
\text { neurship course }\end{array}$ & 33.210 & 26 & 0.156 \\
\hline
\end{tabular}

\section{Conclusion}

Inclination has proven to be the best predictor of planned behavior, particularly when that behavior is rare and difficult to observe. New businesses emerge over time and involve considerable planning. Thus, entrepreneurship is exactly the type of planned behavior (Bird 1988; Katz and Gartner 1988) for which inclination models are ideally suited. Most human activities including starting a new business venture are planned in nature, and not just a response to stimuli, thus reflecting some degree of cognitive processing. A society, thus, benefits if it can predict future direction primarily based on the inclination of its young generation. Hence, if we find that the inclination of young minds is not in the right direction, it may warrant a suitable and timely action by the authorities concerned. When entrepreneurship becomes a national agenda for a country, like Malaysia in 1995, it is all the more necessary to study the entrepreneurial inclination of students, the future generation of the country.

The purpose of this research was to examine the extent to which the young generation, specifically UNITAR students in this case, is inclined toward entrepreneurship. The study found that there was strong entrepreneurial inclination among the students surveyed.They had strong desire to own a business (85\%) and were interested in starting their own businesses (71\%). Further research may be necessary to identify ways and means to convert the desire and interest into actual business activity. Lack of exposure, experience, and 
information on entrepreneurial opportunities and entrepreneurial programs could be factors deterring students from embarking on new venture creation soon after they graduate.

The students in this study were focused on completing their studies. We identified that the respondents, in general, were not willing to drop their studies even when there were some good business opportunities coming their way, which meant that education was deemed to be very important. From this finding, it could be inferred that the next generation of entrepreneurs would come from the educated professionals.

In examining the relationship between students' demographic characteristics and their entrepreneurial inclination, we found no significant difference for gender, work status, and degree status. These findings supported previous studies done on demographic characteristics and entrepreneurial inclination. However, there existed significant difference between students studying full time and part time. Part-time students had greater inclination toward entrepreneurship. The reason for this, we believe, was that many part-time students were already involved in some entrepreneurial activities. Those who were doing some jobs perhaps enrolled for higher education because of dissatisfaction with their jobs and had a greater desire to be entrepreneurs. Student status may have not been considered as a variable in previous studies. In UNITAR's case, however, student status is a salient feature given the nature of its delivery system. Future studies in similar contexts should consider student status as an important variable. The study also found a strong association between family background and entrepreneurial inclination, which therefore supported previous studies.

The study did not find any significant difference between undergraduates and post-graduate students and their inclination toward entrepreneurship. However, there existed significant difference between the type of program students enrolled in and entrepreneurial inclination. Further analysis demonstrated that there were significant differences between the faculties of Business and IT and between the faculties of Business and Humanities, but not for faculties of IT and Humanities. When Business students were included in the analysis, they tended to influence the level of significance between the means. This corroborates the study done by Vangelis, Stefania, and Andreas (2007) where science and engineering students in the UK and France were exposed to entrepreneurship programs and their post-program mean values of subjective norm and intention toward self-employment were increased in relation to the pre-program ones. Based on this, we argue that students from science, engineering, and IT discipline should be given some exposure to entrepreneurship courses.

As discussed earlier, inclination has a predictive validity. However, the inclination may get stronger or may weaken because of facilities or constraints, respectively, that may come in the way of converting an intention into reality. A robust support system should be in place to take advantage of the high entrepreneurial inclination. It is evident from the number of steps taken in the last decade that the Malaysian government is conscious of this phenomenon. Policies like the First Industrial Master Plan, Look East Policy, Malaysia Incorporated, New Economic Policy (1971-1990), New Development Policy, Vision 2020, and the most recent, Multimedia Super Corridor have spawned thousands of new businesses across the broad spectrum of the Malaysian economy.

\section{Limitations and Future Direction}

This exploratory study had its own limitations. The sample for this research was collected from one university in Malaysia. Respondents, in terms of gender, age, and race, were not evenly distributed. Even after the pilot test, some respondents asked for clarity on certain items. Future studies should be extended to a larger sample representing both public and private universities. A comparison could be made between public and private universities to determine if private universities who by their very nature are run by entrepreneurs are able to infuse the spirit of entrepreneurship among students.

\section{References}

Alstete, J. W. 2002. On becoming an entrepreneur:An evolving typology. International Journal of Entrepreneurial Behavior E Research 8(4): 222-234.

Ajzen, I. 1987. Attitudes, traits, and actions: Dispositional prediction of behavior in personality and social psychology. Advances in Experimental Social Psychology 20: 1-63.

Ajzen, I. 1991. The theory of planned behavior. Organizational Bebavior and Human Decision Processes 50: $179-211$.

Ariff, M., and A. B. Syarisa Yanti. 2002. Strengthening entrepreneurship in Malaysia. Malaysian Economic Outlook: 1st Quarter 2002 Update. Proceedings of the 7th corporate economic briefing, 2002, Malaysian Institute of Economic Research (MIER), Malaysia, 1-22.

Audet, J. 2002. A longitudinal study of the entrepreneurial intentions of university students. Paper presented at the annual meeting of the Babson Kaufmann Entrepreneurship Research Conference, Boulder, CO. 
Bagozzi, R., H. Baumgartner, and Y.Yi. 1989. An investigation into the role of intentions as mediators of the attitude-behavior relationship. Journal of Economic Psychology 10:35-62.

Bates, T. 1990. Entrepreneur human capital inputs and small business longevity. The Review of Economics and Statistics 4: 551-559.

Bird, B. 1980. Implementing entrepreneurial ideas:The case for intentions. Academy of Management Review 13:442-454.

Bosma, N., K. Jones, E.Autio, and J. Levie. Global Entrepreneurship Monitor 2007. Retrieved January 10, 2008 available online at http://www.gemconsortium.org/download.asp?fid=644.

Brockhaus, R. H. 1991. Entrepreneurship education and research outside North America. John F. Baugh Center for Entrepreneurship, Hankamer School of Business, Baylor University, Waco,TX.

Cromie, S. 2000. Assessing entrepreneurial inclination: Some approaches and empirical evidence. European Journal of Work and Organizational Psychology 9(1): 7-30.

Department of Statistics Malaysia. 2008. www.statistics.gov.my.

Dyer,W. G. 1994. Toward a theory of entrepreneurial careers. Entrepreneurship Theory and Practice 19(2): 7-22.

Evans, D., and L. Leighton. 1989. Some empirical aspects of entrepreneurship. American Economic Review 79:519-535.

Frank, H., C. Korunka, M. Leuger, and J. Mugler. 2005. Entrepreneurial orientation and education in Austrian secondary school: Status quo recommendation. Journal of Small Business and Enterprise Development 12(2): 259-273.

Gnoth, J. 2006. Perceived motivations and barriers for entrepreneurship amongst NZ students. Proceedings, Understanding the Regulatory Climate for Entrepreneurship and SMEs, Rencontres de St-Gall 2006, September 18-21 2006, Wildhaus.

Gorman, G., Hanlon, D., and King, W. 1997. Some research perspectives on entrepreneurship education, enterprise education and education for small business management: A ten-year literature review. International Small Business Journal 15(3): 56-77.

Guerrero, M., J. Rialp, and D. Urbano. 2008 The impact of desirability and feasibility on entrepreneurial intentions:A structural equation model. The International Entrepreneurship and Management Journal 4(1):35-50.

Genescá, E., and J. M.Veciana. 1984. Actitudes hacia la Creacíon de Empresas. Informacíon Comercial Espãnola 611: 147-155.

Gupta,V. K., and D. B.Turban. 2008. The effect of gender stereotype activation on entrepreneurial intentions. Journal of Applied Psychology, 93(5): 1053-1061.

Gurol,Y., and N.Atsan. 2006. Entrepreneurial characteristics amongst university students: Some insights for entrepreneurship education and training in Turkey. Education + Training 48(1): 25-38.

Hisrich, R. D., and M. P. Peters. 2002. Entrepreneurship, NJ: McGraw Hill.

Jack, S. L., and A. R. Anderson. 1999. Entrepreneurship education within the enterprise culture. International Journal of Entrepreneurial Behaviour \& Research 5(3): 110-25.

Jumaat,A. M.,A. R. Ishak, and M. N. Salehuddin. 2001. Kajian Tentang Sikap Keusahawanan Di Kalangan Belia: Kajian Kes Di Institut Kemahiran Belia Negara Dusun Tua. Proceedings of the 1st national conference on entrepreneurship and small business, School of Management and Entrepreneurial Development Institute, North Malaysia University. Langkawi, Kedah.

Kamariah, O.,A.Yaacob, and W. J. Wan Jamaliah. 2004. A study of entrepreneurial intention among young Malaysians: A case of Universiti Tenaga Nasional's (UNITEN) students. Proceedings of the 3rd international conference on SMEs in a global economy, MARA Technology University, Malaysia, and University of Wollongong, Australia. Holiday Villa Subang, Malaysia.

Katz, J., and W. Gartner. 1988. Properties of emerging organizations. Academy of Management Review 13:429-441.

Koh, H.C. 1995. Factors associated with entrepreneurial inclination:An empirical study of business undergraduates in Hong Kong. Journal of Small Business Entrepreneurship 12(2): 29-41.

Kolvereid, L. 1996. Organizational employment versus self-employment: Reasons for career choice intentions. Entrepreneurship Theory and Practice 21(3): 23-31.

Klapper, R. 2004. Government goals and entrepreneurship education-An investigation at Grande Ecole in France. Education and Training 46(3): 127-137. 
Krueger, N., and D. Brazeal. 1994. Entrepreneurial potential and potential entrepreneurs. Entrepreneurship Theory and Practice 18(1): 91-104.

Krueger, N., M. Reilly, and A. Carsrud. 2000. Competing models of entrepreneurial Intentions. Journal of Business Venturing 15(5/6): 411-532.

Lee, S. M., S. B. Lim, R. D. Pathak, D. Chang, and W. Li. 2006. Influences on students attitudes toward entrepreneurship:A multicountry study. Entrepreneurship Management 2: 351-366.

Li,W. 2007. Ethnic entrepreneurship: Studying Chinese and Indian students in the United States. Journal of Developmental Entrepreneurship 12(4): 449-466.

MacMillan, I., and J. Katz. 1992. Idiosyncratic milieus of entrepreneurship research:The need for comprehensive theories. Journal of Business Venturing 7:1-8.

McClelland, D. C. 1987. Characteristics of successful entrepreneurs. Journal of Creative Behaviour 21(3): 219-33.

Miller, R.A. 1984. Job matching and occupational choice.Journal of Political Economy 92: 1086-1120.

Mueller, S. L., and A. S. Thomas. 2000. Culture and entrepreneurial potential:A nine country study of locus of control and innovativeness. Journal of Business Venturing 16:51-75.

Ngui, C.Y. K. 2005. Getting to the root of graduate unemployment. Malaysian Business. September 16.

Nor Aishah, B. and M.Y.Yufiza. 2004. Motivating factors that influence Class F contractors to become entrepreneurs. Proceedings of the 3rd international conference on SMEs in a global economy, MARA Technology University, Malaysia, and University of Wollongong, Australia. Holiday Villa Subang, Malaysia.

Nor, M., G. Ezlika, and C. C. Ong. 2004. Demographics and personal characteristics of urban Malaysian entrepreneurs: An ethnic comparison. Proceedings of the 3rd international conference on SMEs in a global economy, MARA Technology University, Malaysia, and University of Wollongong, Australia. Holiday Villa Subang, Malaysia.

Noor, M., and J.Ali. 2004. A study of entrepreneurship inclinations among board members of the fishermen's associations. Proceedings of the 1st international Borneo business conference, 2004, University Sarawak Malaysia. Kota Kinabalu, Sabah.

North, D. C. 1990. Institutions, institutional change, and economic performance, New York: Cambridge University Press.

Peterman, N. E., and J. Kennedy. 2003. Enterprise education: Influencing students' perceptions of entrepreneurship. Entrepreneurship Theory and Practice 28(2): 129-144.

Ramayah, T., and Z. Harun. 2005. Entrepreneurial intention among the students of USM. International Journal of Management and Entrepreneurship 1(1): 8-20.

Reynolds, P. D., M. Hay, and S. M. Camp. 1999. Global Entrepreneurship Monitor: 1999 Executive Report. Babson College, Kauffman Center for Entrepreneurial Leadership, London Business School.

Sekaran, U. 2000. Research Methods for Business: A Skill-Building Approach, New York: John Wiley \& Sons Inc., 308-313.

Shapero A. 1982. Social Dimensions of Entrepreneurship. In C. Kent, D. Sexton and K. Vesper, eds., The Encyclopedia of Entrepreneurship. Englewood Cliffs: Prentice-Hall, 72-90.

Schiller, B. R., and P. E. Crewson. 1997. Entrepreneurial origins: A longitudinal inquiry. Economic Inquiry 35: 523-531.

Timmons, J.A. 1989. The entrepreneurial mind. Andover, MA: Brick House Publishing Co. University Press.

Tkachev,A., and L. Kolvereid. 1999. Self-employment intentions among Russian students. Entrepreneurship and Regional Development 11(3): 269-280.

Vangelis, S., Z. Stefania, and Al-Laham Andreas. 2007. Do entrepreneurship programmes raise entrepreneurial intention of science and engineering students? The effect of learning, inspiration and resources. Journal of Business Venturing 22: 566-591.

Veciana, J. M., M. Aponte, and D. Urbano. 2005. University students' attitudes toward entrepreneurship:A two countries comparison. International Entrepreneurship and Management Journal 1: 165-182.

Wang, C. K., and P. K. Wong. 2004. Entrepreneurial interest of university students in Singapore. Technovation 24: 161-172.

Yusop, M. 2002. Keperluan Pengayaan Ilmu dalam Menjayakan Perniagaan Di Kalangan Usahawan Kecil Bumiputera ke Arah Melahirkan Usahawan Industri Kecil Sederhana yang Berjaya. Proceedings of the national IKS finance conference, Langkawi. 
Zimmerer,T.W., and N. M. Scarborough. 2002. Essential of entrepreneurship and small business management. NJ: Pearson Education.

\section{About the Authors}

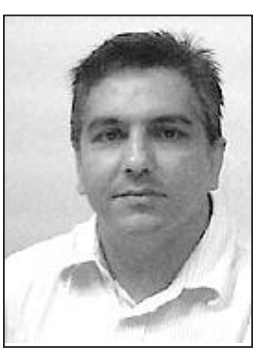

ManjIT Singh SANDHU's (manjit.singh@buseco.monash.edu.my) research interest spans a wide variety of topics such as knowledge economics/knowledge sharing, foreign direct investment, e-banking, competitive advantage of firms, economics of entrepreneurship, leadership, and e-learning. His research papers have been published in refereed journals such as Journal of Workplace Learning, Knowledge Management Review (UK), Malaysian Journal of Distance Education (USM), Malaysian Journal of Educational Technology, Asian Journal of Distance Education, Journal of Contemporary Management Research, Journal for the Advancement of Science and Arts, and Journal of Asia Entrepreneurship and Sustainability.

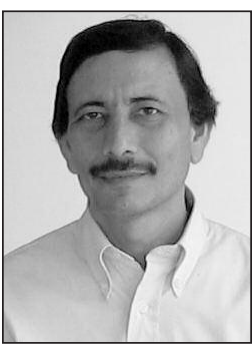

KAMAL KISHORE JAIN (prof_kamal@yahoo.com) is Chair, HR\&OB Area at Indian Institute of Management (IIM), Indore (India), where he is also the Chair, Fellow Program in Management. Before joining IIM Indore, Dr. Jain was a professor at Tun Abdul Razak University, Malaysia. His research interest is in the area of entrepreneurship, leadership, knowledge sharing, and organizational development and change.

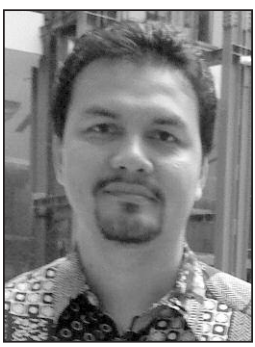

MOHAR YUSOF (mohar@unitar.edu.my) is a Senior Lecturer at the Bank Rakyat School of Entrepreneurship, Tun Abdul Razak University, Malaysia. His area of specialization is academic entrepreneurship and university technology transfer. His other research interest areas include entrepreneurship education, corporate entrepreneurship, and family business. He is a faculty advisor for Students in Free Enterprise at the university and mentors students' entrepreneurial projects. In addition, he provides consultancy and advisory services within the sphere of entrepreneurial development, technology commercialization, and innovation intermediation. 